American Journal of Animal and Veterinary Sciences 6 (3): 125-129, 2011

ISSN 1557-4555

(C) 2011 Science Publications

\title{
Occurrence of Feline Immunodeficiency Virus and Feline Leukemia Virus Infection in Cats
}

\author{
${ }^{1}$ Fabiana Alves, ${ }^{1}$ Daniela de Souza Rajao, \\ ${ }^{1}$ Helen Lima Del Puerto, ${ }^{1}$ Gissandra Farias Braz, \\ ${ }^{1}$ Romulo Cerqueira Leite, ${ }^{1}$ Carlos Mazur, \\ ${ }^{2}$ Almir Sousa Martins and ${ }^{1}$ Jenner Karlisson Pimenta dos Reis \\ ${ }^{1}$ Departament of the Medicine Veterinarian Preventive, \\ Escola de Veterinaria, Universidade Federal de Minas Gerais, \\ UFMG-30 123-970, Belo Horizonte, MG, Brazil \\ ${ }^{2}$ Departamento de Fisiologia e Biofísica, \\ Instituto de Ciencias Biologicas, Universidade Federal de Minas Gerais, \\ Av. Antônio Carlos, 6627, Campus Pampulha, Belo Horizonte, MG,
}

\begin{abstract}
Problem statement: The objective of the present study was to evaluate occurrence of the Feline Immunodeficiency Virus (FIV) and the Feline Leukemia Virus (FeLV) infection in asymptomatic domestic cats in the metropolitan region of Belo Horizonte, Minas Gerais, using the Polymerase Chain Reaction (PCR) for FIV detection and SNAP Combo Plus for FeLV and FIV detection. Approach: Blood samples were collected from the jugular vein of 78 healthy cats, mixed breeds and ages and both sexes. Specific primers were designed for PCR to amplify a $244 \mathrm{bp}$ fragment of FIV gag gene. Results: Five animals $(6.41 \%)$ were positive by PCR and three animals (3.85\%) were positive by SNAP Combo Plus for FIV and 14 animals were positive for FeLV (17.95\%). Conclusion: These results suggest that there is a significant occurrence of asymptomatic infected animals which may serve as potential transmitters of FIV and FeLV.
\end{abstract}

Key words: Belo horizonte, Feline Immunodeficiency Virus (FIV), Feline Leukemia Virus (FeLV), Polymerase Chain Reaction (PCR), asymptomatic infected animals, potential transmitters, minas gerais, domestic cats, via vaginal, clinical history, serologic analysis

\section{INTRODUCTION}

The Feline Immunodeficiency Virus (FIV) and Feline Leukemia Virus (FeLV) belong to the family Retroviridae, they are distributed worldwide and induce persistent infections in domestic cats and other small felids (Hosie et al., 1989; Pedersen et al., 1987; Yamamoto et al., 1989). Between 1.0-20.0\% of domestic cats are infected with FIV in diverse geographic areas of the world, with an overall prevalence of infection between $1.0-15.0 \%$ in healthy cats and from 3.0-44.0\% in sick cats (Bendinelli et al., 1995; Courchamp and Pontier, 1994; Ueland and Lutz, 1992). FeLV infection prevalence rates vary from 1.0$38.0 \%$ (Hosie et al., 1989).

FIV infection is characterized by an impairment of immune functions and a progressive depletion of $\mathrm{CD}^{+}$ cells. The most common clinical signs of FeLV infection are immune suppression, anemia and lymphoma (Hardy et al., 1976). FIV and FeLV infected cats may remain asymptomatic for years; however, eventually succumb due to direct viral effects or, more commonly, to secondary infections resulting from virus-induced immunosuppression (Pedersen et al., 1987; Bendinelli et al., 1995; Hardy et al., 1976; Johnson et al., 1994; Norsworthy et al., 1993; Okada et al., 1994). The saliva of infected cats is the main form of transmission of FIV and FeLV. The transmucosal infection via vaginal and rectal route can also occur, as well as through milk (Hardy et al., 1976; Bachmann et al., 1997; Carpenter et al., 1998). The rate of FIV and FeLV infection is influenced by gender (males greater than females due to roaming behavior); age (older cats are more likely to be infected) and health (sick cats are more likely to be infected, due to an impaired immune system) (Courchamp and Pontier, 1994). 
The methods currently used for detection of FIV infection in domestic cats include virus isolation, immunological tests for detection of specific antibodies and molecular tests for detection of viral genomic sequences (Barlough et al., 1991; Deacon and Leah, 1989; Hohdatsu et al., 1992; Hosie and Jarrett, 1990; Rimstad and Ueland, 1992). Diagnosis of FeLV infection is based on clinical history and viral p27 protein detection in plasma, serum, or saliva of allegedly positive animals. Indirect immunofluorescense (IFA) and immunoenzimatic assays are the most used diagnostic methods (Miyazawa, 2002) and PCR is currently being used (Herring et al., 2001).

The objective of the present study was to evaluate the occurrence of the feline immunodeficiency virus and the feline leukemia virus infection in asymptomatic cats in the metropolitan region of Belo Horizonte, Minas Gerais using Polymerase Chain Reaction (PCR) for FIV detection along with SNAP Combo Plus (IDEXX ${ }^{\circledR}$, Westbrook, ME, USA) for FeLV and FIV detection.

\section{MATERIAL AND METHODS}

Animals: Blood samples were collected from the jugular vein of 78 healthy cats from shelters and private owners, mixed breeds and ages and both sexes. Samples were collected using two sterile disposable vacuum collection tubes, one for serologic analysis and the other one containing anticoagulant (EDTA) for DNA extraction. Animals were clinically examined and clinical signs were documented. All procedures and protocols used in this study were approved by the Universidade Federal de Minas Gerais Animal Experimentation Ethics Committee (101/09). A sample from a positive cat tested by SNAP Combo Plus and by PCR was used as a positive control. PCR reaction with no template was used as a negative control.

DNA extraction: DNA was isolated from whole blood using the NucleoSpin ${ }^{\circledR}$ Blood Columns kit (Machereynagel, Neumann-Neander, Düren, Germany), following the manufacturers protocol. DNA samples were quantified in the NanoDrop (Thermo Fisher Scientific, Wilmington, Delaware, USA) and stored at $20^{\circ} \mathrm{C}$ for further analysis

Polymerase Chain Reaction (PCR) for FIV gag gene: Specific primers were designed for gel-based PCR using the sequences described by Hohdatsu et al. (1992) 5'CTAGGAGGTGAGGAAGTTCA-3' (forward) and 5'-CTGCTTGTTGTTCTTGAGTT-3 (reverse) to amplify a FIV gag gene fragment of 244 bp. DNA was submitted to PCR in accordance with Hohdatsu et al. (1992) with some modifications as follows: an initial incubation at $94^{\circ} \mathrm{C}$ for $5 \mathrm{~min}$, followed by 35 cycles of denaturation at $94^{\circ} \mathrm{C}$ for 1 min, annealing at $55^{\circ} \mathrm{C}$ for $2 \mathrm{~min}$, extension at $72^{\circ} \mathrm{C}$ for $2 \mathrm{~min}$ and a $5 \mathrm{~min}$ final extension at $72^{\circ} \mathrm{C}$. A $25 \mu \mathrm{L}$ reaction consisted of 10X PCR-buffer (Invitrogen Life Technologies, Carlsbad, CA, USA), $3 \mathrm{mM}$ of $\mathrm{MgCl}_{2}$ (Invitrogen Life Technologies, Carlsbad, CA, USA), 1 $\mathrm{mM}$ each dNTP, 1 pmol of each primer and 1 unit of Taq-DNA polymerase (Invitrogen Life Technologies, Carlsbad, CA, USA) and $2 \mu \mathrm{L}$ of DNA (approximately $150 \mathrm{ng})$. PCR products were analyzed in a $8 \%$ polyacrylamide gel stained by silver nitrate.

FIV and FeLV antibody test: Animal's serum samples were used to detect FIV and FeLV antibody, using SNAP Combo Plus kit (IDEXX ${ }^{\circledR}$, Westbrook, ME, USA), following the manufacturers protocol with no modification.

\section{RESULTS}

Contingency tables demonstrate the distribution of PCR and SNAP Combo Plus results by gender (Table 1-3). No statistical evidence by the Chi Square test could differentiate infection percentage in males from females ( $p>0.05)$, for neither FIV nor FeLV.

Table 1: PCR results-occurrence of feline immunodeficiency virus infection in asymptomatic domestic cats in Belo Horizonte, $\mathrm{MG}$

\begin{tabular}{lccc}
\hline & Female $(\%)$ & Male $(\%)$ & Total $(\%)$ \\
\hline Positive & $(2.56)^{\mathrm{a}}$ & $3(3.85)^{\mathrm{a}}$ & $5(6.41)$ \\
Negative & $35(44.87)^{\mathrm{b}}$ & $38(48.72)^{\mathrm{b}}$ & $73(93.59)$ \\
Total & $37(47.43)$ & $41(52.57)$ & $78(100.0)$ \\
\hline
\end{tabular}

a, b: Values with different lowercase letters in the same row differ statistically by Chi Square test $(\mathrm{p}<0.05)$

Table 2: SNAP Combo Plus results-occurrence of feline immunodeficiency virus infection in asymptomatic domestic cats in Belo Horizonte, MG/Brazil

\begin{tabular}{lccc}
\hline & Female $(\%)$ & Male $(\%)$ & Total $(\%)$ \\
\hline Positivez & $0(0)^{\mathrm{a}}$ & $3(3.85)^{\mathrm{a}}$ & $3(3.85)$ \\
Negative & $37(47.43)^{\mathrm{b}}$ & $38(48.72)^{\mathrm{b}}$ & $75(93.15)$ \\
Total & $37(47.43)$ & $41(52.57)$ & $78(100.0)$ \\
\hline
\end{tabular}

a, b: Values with different lowercase letters in the same row differ statistically by Chi Square test $(\mathrm{p}<0.05)$

Table 3: Occurrence of feline leukemia virus infection in asymptomatic domestic cats in Belo Horizonte, MG

\begin{tabular}{lccc}
\hline & Female $(\%)$ & Male $(\%)$ & Total (\%) \\
\hline Positive & $7(8.97)^{\mathrm{a}}$ & $7(8.97)^{\mathrm{a}}$ & $14(17.95)$ \\
Negative & $30(38.46)^{\mathrm{b}}$ & $34(43.59)^{\mathrm{b}}$ & $64(82.05)$ \\
Total & $37(47.44)$ & $41(52.56)$ & $78(100.0)$ \\
\hline a, b:Values with different lowercase letters in the same row differ & \\
\multicolumn{2}{l}{ statistically by Chi Square test $(\mathrm{p}<0.05)$} &
\end{tabular}




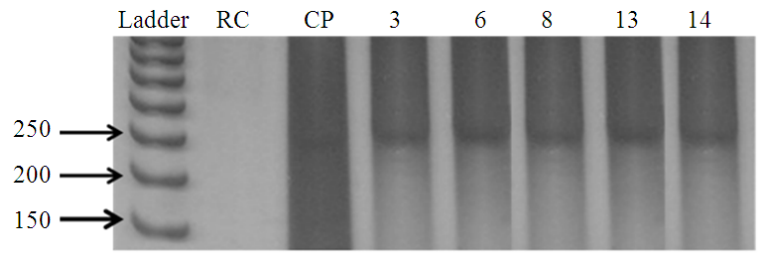

Fig. 1: $8 \%$ polyacrylamide eletrophoresis gel, stained by silver nitrate. Ladder-50 bp ladder; (RC) PCR reaction control; (PC) positive control; samples $3,6,8,13$ and 14 are FIV positive $(6.76 \%)$

All infected animals were more than 2 years old and were asymptomatic at the time of the sample collections. PCR results revealed FIV gag gene detection in four cats $(5.13 \%)$ (Fig. 1). In addition, SNAP Combo Plus results showed antibody detection against FIV in three $(3.8 \%)$ cats, while for FeLV in eleven (14.10\%). No animal was positive for both FIV and FeLV simultaneously considering results of FIVPCR and FeLV SNAP, however, only one animal was positive for FIV and FeLV in the SNAP.

\section{DISCUSSION}

In the present study occurrences of $6.41 \%$ (PCR) and $3.85 \%$ (SNAP) for FIV and $17.95 \%$ (SNAP) for FeLV infection were found in Belo Horizonte's metropolitan area. These results were different from the results found for FIV in Sao Paulo (14.7\%) (Lara et al., 2008), Rio Grande do Sul (37.5\%) (Caldas et al., 2000), Rio de Janeiro (20.2\%) (Souza et al., 2002) and Minas Gerais (2.7\%) (Caxito et al., 2006). Results found for FeLV were similar to those found in different Brazilian states. Reche et al. (1997) and Souza et al. (2002) found 8 and $17 \%$ of positive cats in Sao Paulo and Rio de Janeiro, respectively (Souza et al., 2002; Reche et al., 1997). The variability of serological and molecular diagnosis of feline immunodeficiency virus infection have been reported lately in others researches, in agreement with our study (Bienzle et al., 2004; Mortola et al., 2004). Seronegative samples with PCR positive results may be also found in cats living in close contact with FIV infected seropositive animals, becoming infected without developing antibodies or disease (Dandekar et al., 1992). However, such cats will usually seroconvert weeks to months later (Hosie et al., 2009).

FIV infection rate of $6.41 \%$ found in the present study in asymptomatic animals differ from the rate of $1.47 \%$ found by Caxito et al. (2006), in healthy animals in the same state, Minas Gerais. Authors also found an infection rate of $13.95 \%$ in sick cats, which confirms other data that demonstrate a higher susceptibility of sick animals to FIV infection (Hosie et al., 1989; Ishida et al., 1989). Minas Gerais and Sao Paulo states revealed that FIV infection was more prevalent in male ( $4.38 \%$ and $20.3 \%$, respectively) than in female cats (0.90 and 9.7\%, respectively) (Caxito et al., 2006). However, in present results FIV and FeLV infection rate in male and female could not be differentiated, in agreement with similar results described in Rio de Janeiro (Souza et al., 2002; Teixeira et al., 2007).

\section{CONCLUSION}

Additionally, FIV and FeLV infection in housed cats was more elevated than in sheltered cats and these results are in accordance with the results found by Caxito et al. (2006) and Lara et al. (2008) in which housed cats (3.05\% and $23.1 \%$, respectively) had a higher FIV infection percentage comparing to street cats $(1.11 \%$, $5.9 \%$, respectively). However, high FIV and FeLV infection rates are associated to cats with free street access, which frequently show more aggressive behavior (Hosie et al., 1989; Hosie and Jarrett, 1990; Ishida et al., 1989; Bandecchi et al., 1992). According to animals age, 3.85 and $14.10 \%$ of FIV and FeLV infected cats were more than two years old, which are in the age group with the higher infection incidence. Hosie et al. (1989), showed that infection frequently occurs after the first year of age and its prevalence is higher in elderly cats. Serological studies showed the presence of anti-FIV antibodies in Sao Paulo (20.5\%) (Reche et al., 1997) and Rio de Janeiro (16.7 and 21.0\%) state (Souza et al., 2002; Reche et al., 1997; Mendes-de-Almeida et al., 2004). The higher number of anti-FIV cats in Sao Paulo and Rio de Janeiro comparing to Belo Horizonte, it's probably because serological methods are less specific and can generate false positive results (Hosie and Jarrett, 1990). However, obtaining a reliable diagnosis is important because FIV is a transmissible and infectious disease. Serological tests have limitations, so confirmation of positive ELISA results by western blot should be recommended (Hosie et al., 2009).

Epidemiological studies of FIV and FeLV infection are essential for prevention of virus dissemination in domestic cats. The diagnosis is an important tool to determine the environment of FIV and FeLV circulation and positive cats should be segregate from uninfected ones. The early diagnosis of FIV and FeLV infection is also important for its zoonotic aspect, since immunossupressed animals are likely to eliminate larger quantities of pathogens (O'Neil et al., 1991), such as Toxoplasma gondii (Witt et al., 1989), or Cryptococcus neoformans (Malik et al., 1992). In 
conclusion, FIV and FeLV accurate diagnosis at an early stage for the identification of subclinically infected cats, that contribute to the diffusion of disease, is required to quarantine any infected animals and to prevent the spread of the virus.

\section{ACKNOWLEDGEMENT}

This study was supported financially by CNPq, FAPEMIG and INCT de Informaçao Genético-Sanitária da Pecuária Brasileira. The authors would like to thank Dr.Elizabeth Maria Biondini Jardim from veterinary clinic "Recanto Animal"; Prof. Dr. Cleuza Maria de Faria Resende, Plínio Ferreira Mantovane, Prof. Dr. Adriane Pimenta da Costa Val and Shemina Romano Diniz from Veterinary School of Universidade Federal de Minas Gerais, for providing animal samples.

\section{REFERENCES}

Bachmann, M.H., C. Mathiason-Dubard, G.H. Learn, A.G. Rodrigo and D.L. Sodora et al., 1997. Genetic diversity of feline immunodeficiency virus: Dual infection, recombination and distinct evolutionary rates among envelope sequence clades. J. Virol., 71: 4241-4253. PMID: 9151811

Bandecchi, P., D. Matteucci, F. Baldinotti, G. Guidi and F. Abramo et al., 1992. Prevalence of feline immunodeficiency virus and other retroviral infections in sick cats in Italy. Vet. Immunol. Immunopathol., 31: 337-345. DOI: 10.1016/01652427(92)90020-Q

Barlough, J.E., C.D. Ackley, J.W. George, N. Levy and R. Acevedo et al., 1991. Acquired immune dysfunction in cats with experimentally induced feline immunodeficiency virus infection: comparison of short-term and long-term infections. J. Acquir. Immune. Defic. Syndr., 4: 219-227. PMID: 1671410

Bendinelli, M., M. Pistello, S. Lombardi, A. Poli and C. Garzelli et al., 1995. Feline immunodeficiency virus: An interesting model for AIDS studies and an important cat pathogen. Clin. Microbiol. Rev., 8: 87-112.

Bienzle, D., F. Reggeti, X. Wen, S. Little and J. Hobson et al., 2004. The variability of serological and molecular diagnosis of feline immunodeficiency virus infection. Can. Vet. J., 45: 753-757.

Caldas, A.P.F., E.D.S. Leal, E.F.A. Silva and A.P. Ravazzolo, 2000. Detection of feline immunodeficiency provirus in domestic cats by polymerase chain reaction. Pesq Vet. Bras. DOI: 10.1590/S0100-736X2000000100002
Carpenter, M.A., E.W. Brown, D.W. MacDonald and S.J. O'Brien, 1998. Phylogeographic patterns of feline immunodeficiency virus genetic diversity in the domestic cat. Virology, 251: 234-243. DOI: 10.1006/viro.1998.9402

Caxito, F.A., F.M. Coelho, M.E. Oliveira and M. Resende, 2006. Feline immunodeficiency virus subtype B in domestic cats in Minas Gerais, Brazil. Vet. Res. Commun., 30: 953-956. DOI: 10.1007/s11259-006-3363-8

Courchamp, F. and D. Pontier, 1994. Feline immunodeficiency virus: An epidemiological review. C R Acad. Sci. III., 317: 1123-1134. PMID: 7697467

Dandekar, S., A.M. Beebe, J. Barlough, T. Phillips and J. Elder et al., 1992. Detection of Feline Immunodeficiency Virus (FIV) nucleic acids in FIV-seronegative cats. J. Virol., 66: 4040-4049. PMID: 1318395

Deacon, N.J. and M. Leah, 1989. The potential of the polymerase chain reaction in veterinary research and diagnosis. Aust. Vet. J., 66: 442-444. DOI: 10.1111/j.1751-0813.1989.tb13573.x

Hardy, W.D., Jr., P.W. Hess, E.G. MacEwen, A.J. McClelland and E.E. Zuckerman et al., 1976. Biology of feline leukemia virus in the natural environment. Cancer Res., 36: 582-588. PMID: 175919

Herring, I.P., G.C. Troy, T.E. Toth, E.S. Champagne and J.P. Pickett $e t$ al., 2001. Feline leukemia virus detection in corneal tissues of cats by polymerase chain reaction and immunohistochemistry. Vet. Ophthalmol, 4: 119-126. DOI: 10.1046/j.14635224.2001.00187.x

Hohdatsu, T., M. Yamada, M. Okada, M. Fukasawa and K. Watanabe et al., 1992. Detection of feline immunodeficiency proviral DNA in peripheral blood lymphocytes by the polymerase chain reaction. Vet. Microbiol., 30: 113-123. DOI: 10.1016/0378-1135(92)90107-5

Hosie, M.J. and O. Jarrett, 1990. Serological responses of cats to feline immunodeficiency virus. AIDS, 4: 215-220. PMID: 2161670

Hosie, M.J., C. Robertson and O. Jarrett, 1989. Prevalence of feline leukaemia virus and antibodies to feline immunodeficiency virus in cats in the United Kingdom. Vet. Rec., 125: 293-297. PMID: 2554556

Hosie, M.J., D. Addie, S. Belak, C. Boucraut-Baralon and H. Egberink et al., 2009. Feline immunodeficiency. ABCD guidelines on prevention and management. J. Feline Med. Surg., 11: 575-584. DOI: 10.1016/j.jfms.2009.05.006 
Ishida, T., T. Washizu, K. Toriyabe, S. Motoyoshi and I. Tomoda et al., 1989. Feline immunodeficiency virus infection in cats of Japan. J. Am. Vet. Med. Assoc., 194: 221-225. PMID: 2537270

Johnson, C.M., B.A. Torres, H. Koyama and J.K. Yamamoto, 1994. Tenth anniversary perspectives on AIDS. FIV as a model for AIDS vaccination. AIDS Res. Hum. Retroviruses, 10: 225-228. PMID: 8018382

Lara, V.M., S.A. Taniwaki and J.P.A. Junior, 2008. Occurrence of feline immunodeficiency virus infection in cats. Cienc. Rural. DOI: 10.1590/S0103-84782008000800024

Malik, R., D.I. Wigney, D.B. Muir, D.J. Gregory and D.N. Love, 1992. Cryptococcosis in cats: Clinical and mycological assessment of 29 cases and evaluation of treatment using orally administered fluconazole. J. Med. Vet. Mycol., 30: 133-144. PMID: 1588463

Mendes-de-Almeida, F., M.C.F. Faria, A.S. Branco, M.L. Serrao and A.M. Souza, 2004. Sanitary conditions of a colony of urban feral cats (Felis catus Linnaeus, 1758) in a zoological garden of Rio de Janeiro, Brazil. Rev. Inst. Med. S. Trop., 46: 269-274.

Miyazawa, T., 2002. Infections of feline leukemia virus and feline immunodeficiency virus. Front. Biosci., 7: d504-d518.

Mortola, E., G. Oliva, M. Risso, M. Pecoraro and M.C. Venturini, 2004. Feline immunodeficiency virus infection: A comparative study of different diagnostic techniques. Arq. Bras. Med. Vet. Zootec., 56: 13-18.

Norsworthy, G.D., 1993. Feline Practice. 1st Edn., Lippincott, Philadelphia, ISBN: 039751204X, pp: 688.

O’Neil, S.A., M.R. Lappin, J.S. Reif, A. Marks and C.E. Greene, 1991. Clinical and epidemiological aspects of feline immunodeficiency virus and Toxoplasma gondii coinfections in cats. J. Am. Anim. Hospital Assoc., 27: 211-220.

Okada, S., R. Pu, E. Young, W.V. Stoffs and J.K. Yamamoto, 1994. Superinfection of cats with feline immunodeficiency virus subtypes A and B. AIDS Res. Hum. Retroviruses, 10: 1739-1746. PMID: 7888234
Pedersen, N.C., E.W. Ho, M.L. Brown and J.K. Yamamoto, 1987. Isolation of a T-lymphotropic virus from domestic cats with an immunodeficiency-like syndrome. Science, 235: 790-793. DOI: 10.1126/science. 3643650

Reche, J.R.A., M.K. Hagiwara and S.R.R. Lucas, 1997. Clinical study of acquired immunodeficiency syndrome in domestic cats in Sao Paulo. Braz J. Vet. Res. Anim. Sci., 34: 152-155.

Rimstad, E. and K. Ueland, 1992. Detection of feline immunodeficiency virus by a nested polymerase chain reaction. J. Virol. Methods, 36: 239-248. DOI: 10.1016/0166-0934(92)90055-I

Souza, H.J.M., C.H.R. Teixeira and R.F.S. Graça, 2002. Estudo epidemiológico de infecções pelo vírus da leucemia e/ou imunodeficiência felina, em gatos domésticos do município do Rio de Janeiro. Clin. Vet., 36: 14-21.

Teixeira, B.M., D.S. Rajao, J.P.A. Haddad, R.C. Leite and J.K.P. Reis, 2007. Occurrence of feline immunodeficiency virus and feline leukemia virus in Sheltered domestic cats of Belo Horizonte. Arq. Bras. Med. Vet. Zootec. DOI: 10.1590/S010209352007000400019

Ueland, K. and H. Lutz, 1992. Prevalence of feline leukemia virus and antibodies to feline immunodeficiency virus in cats in Norway. J. Vet. Med., Series B., 39: 53-58. DOI: 10.1111/j.14390450.1992.tb01137.x

Witt, C.J., T.R. Moench, A.M. Gittelsohn, B.D. Bishop and J.E. Childs, 1989. Epidemiologic observations on feline immunodeficiency virus and Toxoplasma gondii coinfection in cats in Baltimore, Md. J. Am. Vet. Med. Assoc., 194: 229-233. PMID: 2537272

Yamamoto, J.K., H. Hansen, E.W. Ho, T.Y. Morishita and T. Okuda et al., 1989. Epidemiologic and clinical aspects of feline immunodeficiency virus infection in cats from the continental United States and Canada and possible mode of transmission. J. Am. Vet. Med. Assoc., 194: 213-220. PMID: 2537269 